April 2006

\title{
Martha Graham, Professor Miller and the "Work For Hire" Doctrine: Undoing the Judicial Bind Created by the Legislature
}

Nancy S. Kim

California Western School of Law

Follow this and additional works at: https://digitalcommons.law.uga.edu/jipl

Part of the Entertainment, Arts, and Sports Law Commons, Intellectual Property Law Commons, and the Theatre and Performance Studies Commons

\section{Recommended Citation}

Nancy S. Kim, Martha Graham, Professor Miller and the "Work For Hire" Doctrine: Undoing the Judicial Bind Created by the Legislature, 13 J. INTELL. PROP. L. 337 (2006).

Available at: https://digitalcommons.law.uga.edu/jipl/vol13/iss2/3

This Article is brought to you for free and open access by Digital Commons @ University of Georgia School of Law. It has been accepted for inclusion in Journal of Intellectual Property Law by an authorized editor of Digital Commons @ University of Georgia School of Law. Please share how you have benefited from this access For more information, please contact tstriepe@uga.edu. 


\title{
MARTHA GRAHAM, PROFESSOR MILLER AND THE "WORK FOR HIRE" DOCTRINE: UNDOING THE JUDICIAL BIND CREATED BY THE LEGISLATURE
}

\author{
Nancy S. Kim*
}

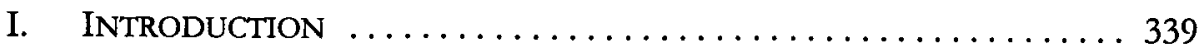

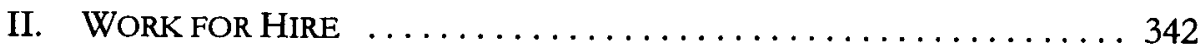

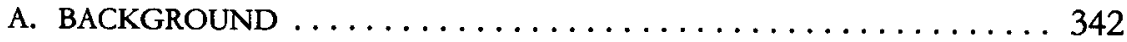

B. THE EFFECT OF A WRITTEN AGREEMENT BETWEEN THE

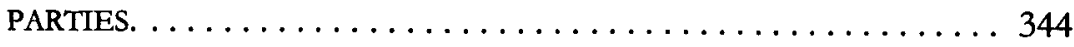

C. JUDICIAL INTERPRETATION OF THE WORK FOR HIRE DOCTRINE. . . . . . . . . . . . . . . . . . . . 347

1. Generally ............................ 347

2. Employment and the Creative Genius ................ 349

a. The Martha Grabam Case ..................... 349

i. The Intent of the Parties ..................... . . 354

3. Employment and the Academic ................. 357

a. Professor Miller and Harvard Law School . . . . . . . . . . . . 357

i. The Teacher Exception ..................... 357

III. Proposals to Change the "All or Nothing" APPROACH OF THE WORK FOR HIRE DOCTRINE $\ldots \ldots \ldots \ldots \ldots . \ldots 2$

A. THE PROPOSED AMENDMENTS $\ldots \ldots \ldots \ldots \ldots \ldots \ldots \ldots \ldots \ldots$

1. Amendment to 17 U.S.C. $\int 101$-Reversing the Statutory Default .......................... 364

2. Amendment to 17 U.S.C. $\int 201$-Enforcing the

Reasonable Expectations of the Parties ...................... 366

a. Does the Employer Have an Implied License to the Work? . . . . . 368

* Assistant Professor, Califomia Western School of Law. B.A., University of Califomia, Berkeley, 1987; J.D., University of California, Berkeley, 1990; LL.M., University of Califomia, Los Angeles, 1993. For their helpful comments and suggestions, I am grateful to Tom Barton, Scott Burnham, Art Campbell, Andrea Johnson, Andy Klein, and the participants at the Southeastern Association of Law Schools' 2005 Young Scholars Workshop. Special thanks to Seth Burns for much encouragement and support during the writing of this Article. My work was much facilitated by the excellent California Western library staff. I gratefully acknowledge the support of a California Western Junior Faculty summer research stipend. All errors are mine alone. 
Journal of Intellectual Property Law, Vol. 13, Iss. 2 [2006], Art. 3

338

$$
\text { J. INTELL PROP. L. }
$$

[Vol. 13:337

i. Purpose of the Employment ................. 368

ii. Industry Norms ........................ 369

b. The Scope of the Implied License ................ 370

c. Text of Proposed Amendment to 17 U.S.C. $\int 201$. . . . . . 373

IV. Conclusion $\ldots \ldots \ldots \ldots \ldots \ldots \ldots \ldots \ldots \ldots \ldots \ldots \ldots \ldots \ldots$ 


\section{INTRODUCTION}

In Martha Grabam School and Dance Foundation, Inc. v. Martha Grabam Center of Contemporary Dance, Inc., ${ }^{1}$ the Second Circuit Court of Appeals held that certain choreographed works produced by the deceased international dance celebrity, Martha Graham, were "works for hire" and therefore, owned by her employer, the defendant-appellee, the Martha Graham Center of Contemporary Dance, Inc. (the Center). ${ }^{2}$ As a result, Graham's legatee Protas could not bar the Center from performing the dances nor could he sell or license any rights to them. ${ }^{3}$ The court's decision appears uncontroversial. Protas expended no material effort, creative or otherwise, in developing the works. He was not a relative of Graham. His only claim to the works stemmed from a provision in Ms. Graham's will that left unclear whether she even believed that she owned the rights to the works in question. ${ }^{4}$ Furthermore, his inheritance raised the specter of undue influence as she made him the beneficiary of her will when she was elderly, isolated, and in poor health. ${ }^{5}$

Still, the implications of the court's decision are troubling. The rationale underlying the court's decision would have prevented Martha Graham herself, without an express license from the Center, from performing her own dances or producing shows of her choreographed works. Thus, if Graham's tenure had been terminated by a dispute rather than death, she would not have been permitted to modify or even perform the dances she created without the Center's consent. As amicus in the Grabam II case noted, the primary purpose of the Center was to free Ms. Graham from the business aspects of dance production so that she could devote her time to the creative aspects. ${ }^{6}$ Ironically, the court's decision would enable an entity created to serve Ms. Graham's artistic vision to strip her of all creative (and legal) control.

Yet, the court's decision in Grabam II was not obviously incorrect. A decision in favor of the plaintiff would have prevented the Center from staging productions of Graham's work without Protas's consent, thus restricting the public's enjoyment of her masterpieces. This Article argues that the problems with the court's decision in Grabam II result, not from its application of the work for hire doctrine, but from the statute itself. 17 U.S.C. $\$ \$ 101$ and 201(b) provide

${ }^{1} 380$ F.3d 624 (2d Cir. 2004) [hereinafter Grabam II].

${ }^{2}$ Id.

${ }^{3}$ The court held that of the seventy dances, the Center was entitled to a declaration of ownership of copyright with respect to forty-five. Of the forty-five, eighteen belonged to the Center by assignment, and the remaining twenty-seven were works for hire. Id. at 631 .

${ }^{4}$ See id. at 629; discussion infra Part II.C.2.a.

${ }^{5}$ See discussion infra Part II.C.2.a (quoting trial court hinting at undue influence).

6 See Grabam II, 380 F.3d at 629; discussion infra Part II.C.2.a. 
a default standard of ownership in favor of the employer. Ownership under the Copyright Act of 1976 is an "all-or-nothing" concept, meaning that if a work is deemed to be a work for hire within the meaning of the section, the employer owns everything and the creator is left with nothing. This Article explains how this conception of work for hire undermines the intent of the parties in "creative genius" situations, such as in Martha Graham's case.

The work for hire doctrine is also at the heart of the heated discussion over whether academics are the authors of course materials prepared while under the employ of educational institutions, an issue that has taken on a new prominence due to the increased popularity of distance learning. ${ }^{7}$ A high-profile case involved Arthur Miller, a well-known law professor at Harvard, who entered into an agreement with Concord Law School to produce an online course. Harvard argued that since the course materials were prepared while Miller was employed by Harvard, the materials belonged to Harvard. Professor Miller countered that the materials belonged to him, and that while Harvard was his employer, it did not own everything he created. Harvard's claim to ownership of course materials in this case may seem innocuous because the only "harm" to Professor Miller appears to be to his pecuniary interest.

Yet, if the work for hire doctrine does in fact grant educational institutions ownership of materials prepared by its employees, the implications are farreaching and profound. It would, for example, enable an employer-institution to modify scholarly works produced by its faculty, even if such modifications are contrary to the views held by the writer. On the other hand, if work produced by a professor is deemed to not be a work for hire, universities and other institutions could be subject to infringement claims for reusing materials prepared at their expense and at their direction. Many scholars and commentators have argued that there exists a "teacher exception" to the work for hire doctrine which excludes the work product of faculty at educational institutions. ${ }^{8}$ Even those who believe that there exists a teacher exception would agree that the hiring institutions should be permitted to reuse certain materials. But currently the scope of materials excluded from the teacher exception, as well as the existence of such an exception itself, is uncertain. The development of the potentially lucrative area of distance education increases the possibility of faculty-institution conflict over copyright ownership.?

7 See discussion infra Part II.c.3.

${ }^{8}$ See discussion infra Part II.c.3.a.i.

9 See Andrea L. Johnson, Reconciling Copyright Ownership Policies for Faculty-Autbors in Distance Education, 33 J. L. \& EDUC. 431 (2004). Johnson notes that

[m]any institutions now see a potential market to capture some of the $\$ 225$ billion market for distance education. Moreover, the government has aggressively promoted distance education by authorizing financial aid for 
The problems highlighted by the Grabam II case, as well as the academic work product cases, stem from the all-or-nothing nature of the work for hire provision itself. $^{10}$ A finding that an engagement is a work for hire under the statute automatically results in all ownership being vested in the hiring party. ${ }^{11}$ This result, dictated by the statute, often contradicts business norms and the understanding of one or both of the parties.

The all-or-nothing nature of the work for hire doctrine is exacerbated by the judiciary's focus, most notably in Community for Creative Non-Violence v. Reid, on the issue of the existence of an employment relationship rather than on the more relevant issue of whether the work was created "within the scope" of the "employment." 12 This Article proposes amending 17 U.S.C. \$S 101 and 201 to emphasize the reasonable expectations of the parties rather than the existence (or nonexistence) of an employment relationship. The proposed amendment takes into account the business realities involved where one party is being paid by another party during the period in which the former party creates work to be used by the hiring party. In Part II, I provide an overview of the work for hire doctrine, and discuss how the courts have analyzed and developed the doctrine. In this section, I examine both the Grabam II case and the Miller-Harvard dispute and explain how the existing conception of work for hire fails to capture the expectations of the parties.

In Part III, I set forth my proposed changes to 17 U.S.C. $\int S 101$ and 201. First, I propose that a written agreement be required in order for employee works to be considered works for hire. This proposal reverses the existing pro-employer statutory default. In addition, I advocate abolishing the all-or-nothing concept of ownership in the current statute in favor of a more particularized analysis that emphasizes the expectations of the parties. Instead of focusing on the existence of an employment relationship, the courts should focus on the intent of the parties with respect to the work. Did the parties intend for the employer to have any rights to use the work? In order to address that issue, the courts will need to inquire into the purpose of the employment and industry norms. If such an inquiry

students and funding to develop distance learning programs. . . With institutions now seeing a potential financial windfall to be made in distance education, many institutions have adopted copyright policies under which home institutions have asserted more rights to what the professor does in his or her classroom, particularly when the lecture or course materials are put in an electronic medium.

Id. at 434.

${ }^{10}$ See 17 U.S.C. $\$ 201$ (b) (2000) (stating that "the employer or other person for whom the work was prepared ... owns all of the rights comprised in the copyright").

${ }^{11}$ Id.

12490 U.S. 730,739 (1989). 
results in a finding that the parties reasonably expected the employer to have an implied license to use the work, the courts should then examine the scope of the license by analyzing the employer's ability to exploit the work and the extent of the employer's input and control over the creation of the work.

\section{WORK FOR HIRE}

\section{A. BACKGROUND}

Under the Copyright Act of $1976,{ }^{13}$ original works of authorship fixed in any tangible medium of expression are subject to copyright protection. ${ }^{14}$ Copyright ownership initially vests in the author of the work. ${ }^{15}$ Although the Copyright Act does not define "author," the author is generally understood to be the creator of the work. ${ }^{16}$ The Copyright Act contains an exception, however, for works made for hire. ${ }^{17}$ Under the 1976 Act, work for hire is defined as:

13 The 1976 Act aimed to strike a balance between the interests of authors and artists and the interests of "hiring parties"-publishers and producers. See Julie Katzman, Note, Joint Authorship of Commissioned Works, 89 ColuM. L. REV. 867, 871-72 (1989); see also Alexandra Duran, Comment, Community for Creative Non-Violence v. Reid: The Supreme Count Reduces Predictability by Attributing an Agengy Standard to the Work for Hire Doctrine of the 1976 Copyright Act, 56 BROOK. L. REV. 1081, 1083 (1990) (stating that the "purpose of the 'work for hire' doctrine is to protect the rights of individual authors while providing employers and hiring parties with a provision to secure the usage rights which they financially and editorially support").

${ }^{14} 17$ U.S.C. $\$ 102(a)$. "Works of authorship" include literary works; musical works; dramatic works; pantomimes and choreographic works; pictorial, graphic and sculptural works; motion pictures and other audiovisual works; sound recordings; and architectural works. Id.

1517 U.S.C. $\$ 201$ (a).

${ }^{16}$ See Reid, 490 U.S. at 737 ("As a general rule, the author is the party who actually creates the work, that is, the person who translates an idea into a fixed, tangible expression entitled to copyright protection."). See also Georgia Holmes \& Daniel A. Levin, Who Ouns Course Materials Prepared by a Teacher or Professor? The Application of Copyright Law to Teaching Materials in the Intermet Age, 2000 BYU EDUC. \& L.J. 165, 166-67; Duran, supra note 13, at 1085 ("Generally, the author is the creator of the work-one who translates an idea into a fixed, tangible form.").

17 The work for hire doctrine first developed under common law in order to enable employers to own work for which they had paid. See Bleistein v. Donaldson Lithographing Co., 188 U.S. 239, 248 (1903) ("There was evidence warranting the inference that the designs belonged to the plaintiffs, they having been produced by persons employed and paid by the plaintiffs in their establishment to make those very things." ). See also Rochelle Cooper Dreyfuss, The Creative Employee and the Copyrigbt Act of 1976, 54 U. CHI. L. REV. 590, 596 (1987). The Copyright Act of 1909 codified the doctrine by establishing that in the case of a work for hire, the employer is deemed to be the author and owns the initial copyright. Register of Copyrights, 87th Cong., 1st Sess., Copyright Law Revision: Report on the General Revision of the U.S. Copyright Law 85 (Comm. Print 1961). See also Copyright Act of 1909, ch. 321, 35 Stat. 1075, 1088 (1909) ("[T] he word 'author' shall include an employer in the case of works made for hire.").

The 1909 Act, however, did not define a "work made for hire." Graham II, 380 F.3d at 634. 
(1) a work prepared by an employee within the scope of his or her employment; or

(2) a work specially ordered or commissioned for use as a contribution to a collective work, as a part of a motion picture or other audiovisual work, as a translation, as a supplementary work, as a compilation, as an instructional text, as a test, as answer material for a test, or as an atlas, if the parties expressly agree in a written instrument signed by them that the work shall be considered a work made for hire. ${ }^{18}$

Under 17 U.S.C. $\$ 201(b)$ :

In the case of a work made for hire, the employer or other person for whom the work was prepared is considered the author for purposes of this title, and, unless the parties have expressly agreed otherwise in a written instrument signed by them, owns all the rights comprised in the copyright.

Thus, where the work is created by an employee within the scope of employment, Section 101 reverses the general presumption under the Copyright Act that the creator is the author of the work, and therefore, the owner of the copyright to that work. In the case of a work for hire, the employer or other person for whom the work was prepared is considered the author and owns the copyright unless the parties have otherwise agreed in writing. ${ }^{19}$ The determination of whether a work is a work for hire within the meaning of the Copyright Act also determines who owns all the rights contained within the copyright of that work. Accordingly, the classification of a work determines many aspects of the copyright in addition to ownership, including the termination of the license grant, ${ }^{20}$ the

${ }^{18} 17$ U.S.C. $\$ 101$ (2000). The Section further states that:

[a] 'supplementary work' is a work prepared for publication as a secondary adjunct to a work by another author for the purpose of introducing, concluding, illustrating, explaining, revising, commenting upon, or assisting in the use of the other work, such as forewords, afterwords, pictorial illustrations, maps, charts, tables, editorial notes, musical arrangements, answer material for tests, bibliographies, appendixes, and indexes, and an 'instructional text' is a literary, pictorial, or graphic work prepared for publication and with the purpose of use in systematic instructional activities.

Id.

1917 U.S.C. $\$ 201$ (b) (2000).

${ }^{20}$ Under the Copyright Act, the creator of a work may terminate an assignment of rights to another party after thirty-five years. If, however, the work is a work for hire, the termination right does not apply. 17 U.S.C. $\$ 203$ (a) (2000). 
duration of the copyright, ${ }^{21}$ and renewal rights. ${ }^{22}$ In addition, only the owner of the copyright may create or authorize derivative works based upon the copyrighted work. ${ }^{23}$

\section{B. THE EFFECT OF A WRITTEN AGREEMENT BETWEEN THE PARTIES}

The work for hire doctrine determines copyright ownership in the absence of an express written agreement between the parties. ${ }^{24}$ This statutory default favors ownership by the hiring party where the hiring party is an employer and the work was prepared by an employee "within the scope of his or her employment." 25 In that case, the work is deemed to be a work for hire regardless of how the parties characterize their relationship or the nature of the work. The employer is considered the author and the initial copyright vests with the employer. ${ }^{26}$ The employer thus owns all the copyrights unless the parties have agreed in writing to transfer ownership to the employee. ${ }^{27}$

If, however, the creator is not an employee, the default rule regarding ownership favors the creator/independent contractor. ${ }^{28}$ In that case, a written agreement must exist between the parties in order for the work to be considered "made for hire."29 If such a writing does not exist, then the work is deemed not to be a work for hire within the meaning of the statute and copyright ownership belongs to the independent contractor. ${ }^{30}$

The language of the statute, and court decisions interpreting that language, indicate that an agreement between an employee and an employer characterizing the nature of the relationship would be insufficient to resolve the issue of

${ }^{21}$ Under 17 U.S.C. $\$ 302$ (a), copyright in a work created on or after January 1,1978 endures for the life of the author and seventy years thereafter. In the case of a work for hire, however, the copyright endures for a term of ninety-five years from the year of its first publication, or a term of 120 years from the year of its creation, whichever expires first. 17 U.S.C. 302(c) (2000).

${ }_{22}$ Only the author is entitled to the renewal rights set forth in 17 U.S.C. $\$ 304$.

${ }^{23} 17$ U.S.C. $\$ 106(2000)$.

${ }^{24}$ See Grabam II, 380 F.3d 624, 634 (2d Cir. 2004).

${ }^{25} 17$ U.S.C. $\$ 101(2000)$.

${ }^{26} 17$ U.S.C. $\$ 201$ (a) states that "[c]opyright in a work protected under this title vests initially in the author or authors of the work." Subsection (b) states that "[i]n the case of a work made for hire, the employer or other person for whom the work was prepared is considered the author for purposes of this title...."

${ }_{27} 17$ U.S.C. \$\$ 201(b), 204(a); see also Jasper v. Bovina Music, Inc., 314 F.3d 42, 46-47 (2d Cir. 2002).

28 See Bovina Music, 314 F.3d at 46-47.

2917 U.S.C. $\$ 101$ (stating that a work for hire is a "work specially ordered or commissioned ... if the parties expressly agree in a written instrument signed by them that the work shall be considered a work made for hire').

${ }^{30}$ Id. 
ownership. The United States Court of Appeals for the Seventh Circuit, for example, recently observed how parties could manipulate contract wording to achieve a particular result which may be contrary to reality. In Gaiman $\nu$. McFarlane, the Seventh Circuit remarked that the "work for hire concept isn't limited to formal employment because a functionally identical relationship can be created by skillful drafting of contracts that purport to treat the (de facto) employee as an independent contractor." hire" if it is a work prepared by an employee within the scope of employment, regardless of whether the parties have inaccurately or falsely stated that it is not. ${ }^{32}$ The United States Court of Appeals for the Second Circuit discussed that very issue under a different provision of the 1976 Copyright Act in Marvel Cbaracters, Inc. v. Simon. ${ }^{33}$ In Marvel Characters, the parties, a comic book author and a publisher, entered into a settlement agreement nearly thirty years after the completion of the work. The court analyzed the settlement agreement under section 304(c) of the 1976 Act which states that transfers of copyrights are subject to termination unless the work is one made for bire. ${ }^{34}$ Under section 304(c)(5), a copyright may be terminated "notwithstanding any agreement to the contrary." The court in Marvel held that the settlement agreement between the parties was an "agreement to the contrary" and that the defendant comic book author was not bound by the statement in the settlement agreement that the work was one created "for hire." 36

Because the court opinion in Marvel focused on the issue of work for hire within the context of section 304(c), it is unclear whether, and to what extent, it would apply to an agreement entered into by the parties prior to the creation of the work. There is authority supporting the view that agreements, at least those in favor of employers, would not be upheld. The Marvel court cited Nimmer on Copyright to support its holding that the parties' characterization of their relationship did not conclude the issue of whether the work was in fact created within the scope of an employment relationship:

The parties to a grant may not agree that a work shall be deemed one made "for hire" in order to avoid the termination provisions if a "for hire" relationship ... does not in fact exist between them.

31360 F.3d 644, 650 (7th Cir. 2004).

32 See Robert A. Kreiss, Scope of Employment and Being an Enployee Under the Work-Made-For Hire Provision of the Copyright Law: Applying the Common-Law Agengy Tests, 40 U. KAN. L. REV. 119, 145-46 (1991).

${ }^{33} 310$ F.3d 280 (2d Cir. 2002).

${ }^{34}$ See id. at 289.

3517 U.S.C. $\$ 304(c)(5)$

36310 F.3d at 292. 
Such an avoidance device would be contrary to the statutory provision that " $[t]$ ermination of the grant may be effected notwithstanding any agreement to the contrary." ... [T] is the relationship that in fact exists between the parties, and not their description of that relationship that is determinative. ${ }^{37}$

As the Second Circuit noted, courts engaging in an analysis of work for hire have "focused on the actual relationship between the parties, rather than the language of their agreements." ${ }^{38}$.As the court in Marvel further noted:

[T] he manner in which the parties designate the relationship is not controlling, and if an act done by one person in behalf of another is in its essential nature one of agency, the one is the agent of such other notwithstanding that he or she is not so called. Conversely, the mere use of the word "agent" by parties in their contract does not make one an agent who, in fact, is not such. ${ }^{39}$

Thus the determination of whether a work is for hire will depend upon the results of a factual inquiry regarding whether an employment relationship between the hiring party and the creator exists and, if so, whether the work created was "within the scope of employment." 40 Thus, under the statute as currently drafted, the intent of the parties regarding ownership of the work is irrelevant where the parties are in an

${ }^{37}$ Id. at 291 (citing 3 MELVILle B. NimMER \& DAVID Nimmer, Nimmer ON COPYRIGHT $\$ 11.02[\mathrm{~A}][2]$ (Matthew Bender 2000) (1963).

38310 F.3d at 291.

39 Id. (citing 3 AM. JUR. 2D Agency $₫ 19$ (2002)). Yet, because the legislative intent underlying the 1976 Copyright Act is to encourage creativity and protect creators from unfair bargaining positions, an agreement resolving the issue of work for hire in favor of the employee might be more susceptible to withstanding judicial scrutiny, even though a different analysis would not be merited under the statute itself. See discussion infra Part II.C.1 (discussing judicial interpretation of the work for hire doctrine).

${ }^{40}$ See Rochelle Cooper Dreyfuss, The Creative Employee and the Copyright Act of 1976, 54 U. CHI. L. REV. 590 (1987)

All work within the scope of employment now constitutes work made for hire, and while the incidents of copyright ownership remain subject to negotiation between employer and employee, only a writing signed by both parties may rebut the presumption in favor of the employer's ownership. Furthermore, authorship of work clearly created within the scope of employment now vests irrebuttably in the employer. ... Accordingly, the circumstances under which the work was created and the expectations of the parties have now become largely irrelevant. The dispositive issue is whether production of scholarly material is "within the scope of employment," that is, a part of the job.

Id. at $598-99$. 
employee/employer relationsbip. ${ }^{41}$ Therefore, it would be a mistake, albeit a tempting one, to view written agreements between the parties as conclusive of whether a work can safely be labeled one for hire. ${ }^{42}$ Such an agreement is, however, relevant to the issue of whether the copyright was subsequently transferred. ${ }^{43}$ Notwithstanding the initial ownership of copyright, under Section 201, the copyright to a work for hire can be transferred from the "author" to another party, including the creator. ${ }^{44}$

The characterization of both the relationship and of the work is of paramount importance as it determines who is the author, which in turn determines who owns the initial copyright. Yet, the characterization is not one that can be made by the parties. The parties cannot contractually determine whether a work is or is not one for hire. Rather, the determination is made by a court after making a factual inquiry.

\section{JUDICIAL INTERPRETATION OF THE WORK FOR HIRE DOCTRINE}

1. Generally. The 1976 Copyright Act left many terms undefined, including "employee" and "employer." 45 Prior to the Supreme Court decision in Community for Creative Non-Violence $v$. Reid, the courts had adopted a variety of approaches when examining whether a work should be considered a work for hire within the meaning of the 1976 Act. $^{46}$ In Aldon Accessories Ltd. v. Spiegel, Inc., ${ }^{47}$ the Second Circuit held that a work would be "for hire" if the hiring party paid for and actually wielded control over the creation of the work, regardless of whether the creator was an employee or an independent contractor. This view was followed by the Fourth ${ }^{48}$ and Seventh ${ }^{49}$ Circuits. A closely related view held that a work is prepared by an employee whenever the hiring party retains the right to control the product. ${ }^{50}$ The United States Court of Appeals for the Fifth Circuit in Easter Seal Society v. Playboy Enterprises, ${ }^{51}$ on the other hand, applied agency principles to

${ }^{41} I d$.

${ }^{42} I d$.

${ }^{43}$ Id.; see also 17 U.S.C. $\$ \$ 201$ (b), 204 (2000).

4417 U.S.C. $\$ 201(2000)$.

45490 U.S. 731,739 (1989) ("The [1976 Copyright] Act nowhere defines the terms 'employee' or 'scope of employment." ").

${ }^{46}$ For a summary of judicial approaches prior to the Reid decision, see Jennifer Sutherland Lubinski, Comment, The Work for Hire Doctrine Under Community for Creative Non-Violence v. Reid: An Artist's Fair Weather Friend, 46 CATH. U. L. REV. 119, 125-31 (1996).

47738 F.2d 548 (2d Cir. 1984).

48 Brunswick Beacon, Inc. v. Schock-Hopchas Publ'g Co., 810 F.2d 410 (4th Cir. 1987).

49 Evans Newton Inc. v. Chicago Sys. Software, 793 F.2d 889 (7th Cir. 1986).

50 See Peregrine v. Lauren Corp., 601 F. Supp. 828 (D. Colo. 1985); Clarkstown v. Reeder, 566 F. Supp. 137, 142 (S.D.N.Y. 1983).

${ }^{51} 815$ F.2d 323 (5th Cir. 1987). 
determine whether a creator was an employee. The Ninth Circuit ${ }^{52}$ used a multifactor test to hold that only formal, salaried employees were "employees" within the meaning of the 1976 Act. Under this view, independent contractors and freelance artists would never be considered "employees" within the meaning of the work for hire doctrine. ${ }^{53}$

The United States Supreme Court attempted to resolve the conflicting appellate decisions when it granted certiorari in Reid. ${ }^{54}$ In that case, the Community for Creative Non-Violence (CCNV), a nonprofit charitable organization, engaged a sculptor, James Earl Reid, to create a statue depicting the plight of the homeless. ${ }^{55}$ After the statute was completed, each party claimed copyright ownership. CCNV brought suit. The district court found that the sculpture was a work for hire under Section 101 of the Copyright Act. ${ }^{56}$ The United States Court of Appeals for the District of Columbia reversed and remanded, holding that the sculpture was not a work for hire. The Supreme Court affirmed the decision of the appellate court. In doing so, it relied upon the general common law of agency and the agency principles set forth in the Restatement Second in applying a multifactor test to determine whether a hired party was an employee. ${ }^{57}$ The Supreme Court noted that although no one factor is determinative, the nonexhaustive relevant criteria include the source of the instrumentalities and tools; the location of the work; the duration of the relationship between the parties; whether the hiring party has the right to assign additional projects to the hired party; the extent of the hired party's discretion over when and how long to work; the method of payment; the hired party's role in hiring and paying assistants; and whether the work is part of the regular business of the hiring party. ${ }^{58}$

In rejecting the "actual control" and "right to control" tests, the Supreme Court stated that there was no statutory support for a dichotomy between commissioned works that are actually supervised and controlled by the hiring party, and those that are not. ${ }^{59}$ In addition, the Court noted that Section 101(1) does not support the argument that the term "employee" should include only formal, salaried employees. ${ }^{60}$

52 See Dumas v. Gommerman, 865 F.2d 1093, 1102 (9th Cir. 1989).

${ }^{53} \mathrm{Id}$. at 1105.

${ }^{54}$ Cmty. for Creative Non-Violence v. Reid, 488 U.S. 940 (1988).

${ }^{55}$ Cmty. for Creative Non-Violence v. Reid, 490 U.S. 730, 733-34 (1989).

${ }^{56}$ Id. at 735.

${ }^{57}$ Id. at 740 .

58 Id. at $751-52$.

${ }^{59}$ Id. at 742 .

${ }^{60}$ Id. at 743, n. 8 . 


\section{Employment and the Creative Genius.}

a. The Martha Grabam Case. In Martha Grabam School and Dance Foundation, Inc. v. Martha Graham Center of Contemporary Dance, Inc. (the Martha Graham case), the sole heir to the late choreographer Martha Graham's estate sued a dance school and a dance center, claiming ownership of seventy dances. ${ }^{61}$

The defendants were a dance company and a dance school, which Martha Graham had founded as sole proprietorships in the $1920 \mathrm{~s}^{62}$ The dance company was incorporated in 1948 and renamed in 1968 as the Martha Graham Center of Contemporary Dance (the Center). The school was sold to the newly incorporated Martha Graham School of Contemporary Dance, Inc. in 1956 (the School). ${ }^{63}$ The purposes of the School were to "teach the science and art of the dance," and "in conjunction with the conduct of the school, . . . to compose, perform and demonstrate, and to commission the composition, performance and demonstration of dances, ballets, dramas, and music ...." ${ }^{94}$ The Center, a notfor-profit corporation, ${ }^{65}$ operated as an umbrella organization encompassing the School $^{66}$ and the defendants were treated by the district court and the appellate court as one entity. ${ }^{67}$

While the not-for-profit Center and the public arts-oriented School made for sympathetic defendants, the beneficiary-plaintiff, Ronald Protas, made a rather unappealing plaintiff. The court notes that Graham met Protas when she was in her seventies and he was twenty-six. ${ }^{68}$ Although he was a freelance photographer with no previous dance background, Graham "trusted him to represent her in both personal and professional matters." ${ }^{19}$ The trial court hinted at the possibility of undue influence by Protas over Graham as her health declined:

As Graham's physical abilities waned in the final years of her life, Protas became her spokesperson. [A witness] testified credibly at the first trial that Graham did not attend board meetings regularly between 1987 and 1991 and that the board would learn of her views

61380 F.3d 624 (2d Cir. 2004). There were two named plaintiffs, the Martha Graham School and Dance Foundation and Ronald Protas. Id. at 631. The Foundation was created by Protas and does not allege an interest in Graham's estate independently of Protas' interest. Id.

${ }^{62}$ Id. at 629 .

${ }^{63}$ Id.

${ }^{64}$ Martha Graham Sch. \& Dance Found., Inc. v. Martha Graham Ctr. of Contemporary Dance, 224 F. Supp. 2d 567, 572 (S.D.N.Y. 2002) [hereinafter Grabam I].

${ }^{65}$ Id.

${ }^{66}$ Id. To minimize confusion, in this Article, unless otherwise noted, the "Center" will be used to refer to the Center and the School together as one entity.

${ }^{67}$ Grabam II, 380 F.3d 624, 629 n.2 (2d Cir. 2004).

${ }^{68}$ Id. at 629.

${ }^{69}$ Id. 
through Protas: "Ron Protas would say, Martha wants, or Martha said, or Martha would like."”o

Although he was a fiduciary of the defendants, Protas was aware of his personal interests and the potential for conflict. Protas wrote: "I want to do everything possible to strengthen my position, in terms of Martha's will, board people and the sets." 71

Despite his lack of experience in dance, "Protas became an increasingly important figure at the Center." resignations, requested by Graham, of longstanding members of the board who had personal knowledge of the Center's history." ${ }^{73}$ Testimony at trial indicated that Protas falsified board minutes, had "easy access to" and "borrowed" Center funds without permission (and without repayment). ${ }^{74}$

In her last will, Graham named Protas her executor and bequeathed to him her personal property and her residuary estate, including "any rights or interests in any dance works, musical scores, scenery sets, [Graham's] personal papers and the use of [Graham's] name." ${ }^{75}$ The will was signed two years before her death at the age of ninety-six. ${ }^{76}$

Protas became Artistic Director of the Center after Graham's death in 1991. The following year, Protas asserted ownership of copyrights in all of Graham's dances. ${ }^{77}$ In 1998, he placed the copyrights in a revocable trust (the Trust) "that he had created and of which he was trustee and sole beneficiary." under pressure from donors, Protas was removed as Artistic Director of the Center. ${ }^{79}$ Protas, acting through the Trust, established the Martha Graham School and Dance Foundation (the Foundation), a not-for-profit corporation. ${ }^{80}$ Between 2000 and 2001, Protas obtained certificates of registration for thirty of Graham's

${ }^{70}$ Grabam I, 224 F. Supp. 2d at 574-75.

71 Id. at $574-75$.

${ }^{72}$ Id. at 574.

${ }^{73}$ Id.

${ }^{74}$ Id.

${ }^{75}$ Graham II, 380 F.3d 624, 629 (2d Cir. 2004).

${ }^{76}$ Id. The court does not mention Graham's precise age, but the reader of the court's opinion can quickly discern that Graham was in her nineties at the time the will was executed. Furthermore, the court does refer to Judge Cederbaum's opinion which specifically mentions Graham's age at the time she died. See Grabam I, 153 F. Supp. 2d 512, 514 (S.D.N.Y. 2001).

77 Grabam II, 380 F.3d at 630 . Protas also asserted ownership of sets and properties which are not part of the work for hire discussion. Id.

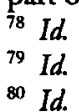


dances and the Foundation became the exclusive licensee in the United States for live performance of Graham's dances. ${ }^{81}$

Protas initiated the lawsuit against the defendants to enjoin them, from among other things, performing seventy of Graham's dances. ${ }^{82}$ The defendants argued that the dances belonged to the Center by virtue of the work for hire doctrine or Graham's assignments. ${ }^{83}$ The United States District Court for the Southern District of New York agreed, and the plaintiff appealed. ${ }^{84}$

The Court of Appeals for the Second Circuit framed the issue before it as "whether the work-for-hire doctrine applies to works created by the principal employee of a corporation that was, in the Appellants' view, created to serve the creative endeavors of an artistic genius." 85 The court noted that the applicable principles of the work for hire doctrine under both the 1909 Act and the 1976 Act $^{86}$ operated as default rules in the event that a contract did not specify ownership. ${ }^{87}$

The Grabam II court discussed the factors applied by the U.S. Supreme Court in Reid and noted that the Second Circuit had accorded "particular significance" to the following factors: "(1) the hiring party's right to control the manner and means of creation; (2) the skill required; (3) the provision of employee benefits; (4) the tax treatment of the hired party; and (5) whether the hiring party has the right to assign additional projects to the hired party." ${ }^{88}$ The Court stated that under the 1976 Act, "a person's status as an employee renders a work created within the scope of employment as a work for hire, as to which the copyright belongs to the employer (in the absence of a contract providing otherwise)."

It then proceeded to examine whether Graham's dances created from 1978 through 1991 were works for hire within the 1976 Copyright Act. ${ }^{90}$ First, the Court determined whether Graham was an "employee." It noted that during 1978-1991, Graham served as the Center's Artistic Director and received

${ }^{81}$ Id. The Center also obtained certificates of registration for initial and renewal terms for some of the dances. Id.

${ }^{82}$ Id. Protas also sought to enjoin the defendants from using the Martha Graham trademark and teaching the Martha Graham Technique. Id.

${ }^{83}$ Id. at 631.

${ }^{84}$ Id. at 628 .

${ }^{85}$ Id. (quoting Brief for Appellants at 20) (emphasis added).

${ }^{86}$ The 1909 Act applies to dances created before January 1, 1978, and the 1976 Act applies to those dances created after that date. To the extent practical, because the topic of this article is the current work for hire provision, I limit discussion to only those dances created after January 1, 1978.

${ }^{87}$ Grabam II, 380 F.3d at 634. See also discussion supra Part II.B.

${ }^{88}$ Id. at 636 n.21 (citing Aymes v. Bonelli, 980 F.2d 857, 861 (2d Cir. 1992)).

${ }^{89}$ Id.

${ }^{90}$ Id. As the Court noted, the 1909 Act is applicable to works created before January 1, 1978. Id. at 632. The Court also reviewed dances created prior to 1978 , but, because those dances are subject to the 1909 Act, this Article does not address them. 
employee benefits and a salary. ${ }^{91}$ During this time, the Center withheld income and social security taxes from her salary and reimbursed her for personal expenses, travel, and medical benefits. ${ }^{92}$ She created her dances at the Center, with the Center's resources, and her choreography was a regular activity of the Center. ${ }^{93}$

The Court conceded that the Center did not exercise much control over Graham's activities, but noted that "the absence of exercise of control did not mean an artist is not an employee where other factors weigh in favor of finding an employment relationship." 94

Protas argued that the work for hire doctrine was inapplicable because of Graham's central role with the Center. ${ }^{95}$ Thus, even if she was "technically a salaried employee" who "choreographed dances at the Center's expense," she did so only as she saw fit. ${ }^{96}$ The Amici Curiae ${ }^{97}$ framed the issue more pointedly as whether the work for hire doctrine should be applied "where the putative 'employer' is a not-for-profit corporation formed for the purpose of encouraging and supporting authors in their creative endeavors." 98 "The court itself acknowledged its judicial bind:

We understand [the appellants'] point that where a corporation is formed for the purpose of fostering a supportive environment in which an employed artist will have the opportunity to create new works, the default rule should leave the copyrights in the new works

${ }^{91}$ Id. at $641-42$.

92 Id.

${ }^{93}$ Id.

94 Id. at 642.

95 Id. at 639.

${ }^{96} I d$.

${ }^{97}$ Id. The Amici Curiae were "the American Dance Festival, Inc., a not-for-profit corporation founded in part by Graham; Gerald Arpino, Artistic Director of the Joffrey Ballet of Chicago; and Gordon Davidson, Artistic Director of the Center Theatre Group/Mark Taper Forum of the Los Angeles County Music Center." Id. at 639 n.34.

${ }^{98}$ Id. a 639 . Some might argue that Ms. Graham should not be permitted to selectively recognize the benefits of such a legal entity without suffering any of the constraints but such arguments ignore that most businesses are created for exactly that reason-to free their owners from potential operational liabilities and management decisions. The issue of corporate alter egos should be distinguished from the issue of work for hire. Granting Ms. Graham ownership of her choreographed works is a far cry from permitting her to use the Center's funds as her own private checkbook, for example. Legitimate businesses may permit their employees to retain intellectual property rights by contract. Thus, if Ms. Graham had known that her choreographed works would be interpreted as works for hire and owned, not by her, but by the Center, she might have signed an agreement with the Center clarifying the issue of ownership or maybe even put a similar ownership statement in the by-laws of the Center. 
with the employee and place on the employer the burden of pursuing a contract to obtain her copyrights. Whatever the intrinsic merit of such an approach, we conclude that its adoption is a matter of legislative choice for Congress in the future, not statutory interpretation for a court at present. ${ }^{99}$

The Court struggled with the issue of the Center's lack of control over Graham's work, stating that " $[t]$ he fact that Graham was extremely talented understandably explains the Center's disinclination to exercise control over the details of her work, but does not preclude the sort of employee relationship that results in a work for hire." ${ }^{100}$ The Court concluded that Graham was an employee with a contractual duty to create dances ${ }^{101}$ and that the choreographed dances were therefore, works for hire. ${ }^{102}$

Whatever qualms the Court may have had about the effect of its decision on creative arts policy, its holding in light of the facts before it is morally satisfying. The plaintiff Protas was depicted as selfish and dishonest. ${ }^{103}$ The district court judge, Miriam Cederbaum, flatly stated that "[o]n the material facts, I found Protas not to be a credible witness" 104 and noted his "evasive and inconsistent testimony" and untrustworthy demeanor. ${ }^{105}$ The Second Circuit Court of Appeals agreed, finding that "the District Court did not err in granting the Defendants' counterclaim for breach of Protas's fiduciary duty to the Center." in his favor would have prevented the Center from performing the dances, to the detriment of the public. Intervenor-Defendant Eliot Spitzer, Attorney General of the State of New York, supported the Center's position that the public interest was aligned with the Center's right to perform the dances. ${ }^{107}$ In addition to

${ }^{99}$ Id. at 640 .

100 Id. at 642.

${ }^{101}$ Having established that Graham was an employee during this time, the Court does not expressly discuss whether the dances were created within the scope of employment, presumably because it has already discussed this issue with respect to the pre-1978 dances.

102 Graham II, 380 F.3d at 640.

${ }^{103}$ For example, the Court notes that there "was evidence that Protas ignored questions that surfaced from several sources about his ownership of the dances, sets, and costumes, and made assertions regarding ownership of these items to the Center's board of directors and to third parties. These assertions were, at best, irresponsibly made, and, at worst, intentionally misleading." Id. at 646. The Court further found that "Protas licensed and sold properties that did not belong to him, for his own enrichment." Id.

104 Grabam I, 153 F. Supp. 2d 512, 514 (S.D.N.Y. 2001). The appellate court refers throughout its decision to the "meticulous opinions" of Judge Cederbaum. See Grabam II, 380 F.3d at 629.

105 Graham I, 224 F. Supp. 2d 567, 571 (2d Cir. 2004).

106 Graham II, 380 F.3d at 646.

${ }^{107}$ Id. at 631. 
severely curtailing the public's enjoyment of Graham's work, a decision in favor of Protas would likely have resulted in the closing of the School and the Center-something that would have surely been contrary to Graham's wishes.

i. The Intent of the Parties. On the facts of the case, the court's decision appears only to harm Protas, who has already proven himself to be unworthy of much sympathy. He was neither a potential employer nor the creator of the dances at issue. He is depicted as greedy, dishonest, and difficult to please. ${ }^{108}$

Yet, the Grabam decision establishes a troubling precedent that becomes evident by examining the effect if Graham herself had been the plaintiff. ${ }^{109}$ The Center and the School were established so that Graham could free herself from funding and legal matters. ${ }^{110}$ Graham was not just another employee of the defendants; she was the most important one. The eponymous School and Center were created solely to teach and perform her dances and dance techniques. In the actual case, Graham was never compelled to leave the employ of the Center because there was no reason to. The purpose of the defendants was to assist Graham in the creation of her works and there appeared to be no significant divergence in interests. The defendants' deference to Graham's wishes even explains Protas's rise to power, despite his lack of qualifications. ${ }^{111}$ The

108 The opinion of the court was restrained when compared to descriptions of Protas in media publications. One publication commented that Protas was "perhaps the most reviled person in dance" and that his "erratic, ingratiating, spiteful, dissembling, un-mindful, vindictive, simpering and quite possibly demented personality" have been on trial. Paul Ben Itzak, If Protas is Defeated, Would Dancers Win the Battle but Lose the War, DANCE INSIDER, Spring 2002. Another publication referred to Protas as "a non-dancer whose influence was controversial from the start. By many accounts, he was a polarizing figure; some longtime dancers quit in protest over his involvement in the company." Jennifer de Poyen, $A$ fragile art form, dance has to be passed on or it dies; the Martha Grabam troupe keeps the flame alive, SAN DIEGo UNION-TRIBUNE, Mar. 6, 2005, at E2.

${ }^{109}$ Protas acted as Graham's beneficiary and the court's decision was not in any way conditional upon the fact that he, as opposed to Graham herself, was the plaintiff.

110 Grabam II, 380 F.3d at 629.

111 The district court's opinion notes that

[U]nder Graham's auspices, Protas became an increasingly important figure at the

Center. His arrival ... was followed shortly by resignations, requested by

Graham, of longstanding members of the board who had personal knowledge of the Center's history. Protas was copied on some of these resignation letters that were received in response to Graham's request. Although he was not a dancer, by the mid-1970s, Protas had become Executive Director of the Center and a board member of the Center and the [Martha Graham] School [of Contemporary Dance] (the "School"). In approximately 1980, he was given the title of Co-Associate Artistic Director.

Grabam I, 224 F. Supp. 2d 567, 574 (2d Cir. 2004). A letter to Protas from Rick Burke, President of the Center and a member of the Board, reveals both the Board's ill will toward Protas and deference to Graham,

'As far as the art is concerned, it concerned me that last year you attempted to 
defendants had no agenda other than to facilitate Graham's creative process. ${ }^{112}$ Graham "gave" her dances to the Center because she understood that the Center would handle the administrative and business issues related to them while enabling her to focus her attention on their creation. ${ }^{113}$ The Center, on the other hand, gave Graham broad discretion and complied with her wishes.

Ironically, the court's holding that the dances she created were "works made for hire," would have enabled the defendants to legally wrest creative control over those dances away from Graham even if she had been alive. The court's ruling means that the defendants could have hired choreographers from other backgrounds to alter Graham's works without her permission and even against her wishes. If Graham had left her position as an employee of the Center, she would have been prevented from using any of her dances in subsequent productions. This curtailment of her creative activity would likely have limited her future employability.

The Grabam II court rendered a decision that ignores the intent of the parties in entering into the employment relationship. Graham was not creating dances requested by the defendants for the benefit of the defendants. Rather, the corporation existed solely to facilitate Graham's creation of the dances for the public good. Yet, the court's decision is the only correct one given both the factual circumstances and the constraints of 17 U.S.C. $\int \$ 101$ and 201(b). Under the current legislation, a finding that a work is one "for hire," means that, absent a written agreement otherwise, the employer/author is the sole owner of the copyright. On the other hand, a finding that the work is not one "for hire" would have given the copyright to the dances to Protas, who clearly intended to prevent the Center from performing the dances. This result is contrary to Graham's intent. She was an employee of the Center at the time of her death and had never indicated that she wished to sever ties with the defendants or diminish their right to use any of her work. In fact, her will reveals that she retained good will toward the defendants, even if she did not make them the beneficiary of her estate:

move the art from the Center back to Martha ... until we had legal advice... . Your action without talking to me, concerned me and other members of the Board. No one disputes you run the show and deserve what ever Martha wants to give you.'

\section{Id. at 575 .}

${ }^{112}$ At trial, Jeanette Roosevelt, a former member of the Board of the Center and former President of the Center and of the School, credibly testified that the Executive Administrator of the Center, the principal managerial employee of the defendants and a board member of the School, "was very loyal to Graham and was concerned that her wishes be met." Id. at 574 .

${ }^{113}$ For example, the Center handled various tax matters related to Graham's income and reviewed requests to perform dances created by Graham. Id. at 573. 
The residue ... of all of my property, real and personal, of every kind and description and wherever situated, including all property over which I may have power of appointment at the time of my death ... I give, devise and bequeath to my said friend, Ron Protas, if he shall survive me, or, if he shall not survive me, to the Martha Graham Center of Contemporary Dance, Inc.

In connection with any rights or interests in any dance works, musical scores, scenery sets, my personal papers and the use of my name, which may pass to my said friend Ron Protas under this Article IV, I request, but do not enjoin, that he consult with my friends ... regarding the use of such rights or interests. ${ }^{114}$

Graham did not specifically state whether she believed that the dances at issue were part of her estate, and it is unclear whether this failure was because she assumed that they were or were not, or whether it was the product of a mistaken belief that it did not matter because the interests of Protas and the defendants were aligned. Graham does not seem to have labored much over her will. Her attorney testified that he prepared it in less than an hour, and that he was not asked to conduct an investigation as to what intellectual property Graham owned. ${ }^{115}$

A corporate entity may be created for any legitimate business purpose. ${ }^{116}$ In this case, the Center was created for the purpose of handling the business affairs of Ms. Graham in order for her to devote her energies to the creative aspects of dance. The court's decision, however, ignores the understanding between the parties and undermines this purpose by divesting the creator of the work from the ownership of the dances, thus barring her from their subsequent development. In most cases, the implications of granting ownership to the Center would have little practical impact as the Center is, or was, subject to Ms. Graham's control. But one can imagine more problematic scenarios. For example, imagine that Ms. Graham were still alive but that the Center had been dissolved due to bankruptcy. The court's judgment permits her works to be sold to creditors as assets of the corporation. The court's decision renders the default in favor of the Center, despite the evidence indicating that the failure to contractually transfer ownership to Ms. Graham, or to provide for joint ownership, was the result of oversight rather than deliberation.

114 Grabam II, 380 F.3d at 629 , n.3.

115 Grabam I, 224 F. Supp. 2d at 576.

116 See MOD. Bus. CORP. ACT $\$ 3.01$ (2002) (providing that "every corporation under this Act has the purpose of engaging in any lawful business unless a more limited purpose is set forth in the articles of incorporation'). 
Not only does the court's decision appear to undermine the original intent of the parties, it also defeats the objective of the Copyright Act to encourage artistic creation. In the example above, because Ms. Graham does not own the rights to the works that she created while an employee of the Center, she would have no right to reuse any of the choreography, including any copyrightable portion of a dance sequence without a license from the Center. This restriction on her ability to reuse certain copyrightable dance sequences or movements would also have prevented her from creating derivative works which would certainly have stifled her creative energies and artistic expression. As a result, a dispirited Ms. Graham would likely have had a very hard time finding subsequent employment.

The Grabam II decision fails to implement the intent of the parties with respect to the nature of Graham's employment relationship and the ownership of the dances. Yet the problem with the Grabam II decision originates, not from the court's rationale, but from the statute itself. Because the statute does not permit or recognize shared ownership or license grants, a contrary decision would have resulted in injury to the public's interest in viewing Graham's dances. In short, the Grabam II court made the best decision it could given the limitations of the work for hire doctrine.

3. Employment and the Academic.

a. Professor Miller and Harvard Law School. Several years ago, Concord Law School, a virtual institution, hired a Harvard Law School professor, Arthur Miller, to produce a lecture series on Civil Procedure. ${ }^{17}$ Harvard Law School claimed that it owned the copyright to Miller's lectures and therefore, either Miller should be enjoined from working for Concord or Harvard should receive a share of the revenue from those lectures. ${ }^{118}$ Miller countered that the lecture materials belonged to him, and that although Harvard was his employer, it did not own everything that he created. ${ }^{119}$ The Harvard-Miller dispute raises several interesting issues regarding whether academic work belongs to the creator employee or to the institution employer.

i. The Teacher Exception. As discussed above, the work for hire doctrine makes the hiring employer the author of a work created by an employee unless otherwise agreed to by the parties in writing. Some courts, however, have established a teacher exception to the work for hire doctrine which enables professors to retain the copyright to their lectures and scholarly works. ${ }^{120}$ The

117 Amy Dockser Marcus, Seeing Crimson: Why Harvard Lay Wants to Rein in One of its Star Professors, WALL ST. J., Nov. 22, 1999, at A1; Chanani Sandler, Comment, Copyright Ownership: $A$ Fundamental of "Academic Freedom," 12 ALB. L.J. SCI. \& TECH. 231 (2001); Johnson, supra note 9, at 433-34.

${ }^{118}$ Sandler, supra note 117, at 232.

119 Marcus, supra note 117.

120 Sandler, supra note 117, at 239. 
teacher exception was generally uncontested by schools, primarily because there was no incentive to object. ${ }^{121}$ As illustrated by the Harvard-Miller dispute however, advances in technology now make it possible for educators and educational institutions to derive significant revenue from such work. ${ }^{122}$ As a result, some schools are claiming copyright ownership of work product created by their professors. ${ }^{123}$ Currently, it is uncertain whether a teacher exception would survive a challenge by an institution under the work for hire doctrine. ${ }^{124}$ The Copyright Act does not acknowledge such an exception. In Hays v. Sony Corp. of America, Judge Posner noted that

[t]o a literalist of statutory interpretation, the conclusion that the Act abolished the exception may seem inescapable. The argument would be that academic writing, being within the scope of academic employment, is work made for hire, per se; so, in the absence of an express written and signed waiver of the academic employer's rights, the copyright in such writing must belong to the employer. ${ }^{125}$

Yet, Posner recognized that such a conclusion would wreak havoc in academic institutions due to "the lack of fit between the policy of the work-for-hire

${ }^{121} I d$. at 246.

${ }^{122}$ Id. Professor Johnson notes that:

$[\mathrm{m}]$ any institutions now see a potential market to capture some of the $\$ 225$ billion market for distance education. ... . With institutions now seeing a potential financial windfall to be made in distance education, many institutions have adopted copyright policies under which home institutions have asserted more rights to what the professor does in his or her classroom, particularly when the lecture of course materials are put in an electronic medium.

Johnson, supra note 9, at 434. See also Ashley Packard, Copyright or Copy Wrong: An Anabysis of University Claims to Faculty Work, 7 COMM. L. \& POL'Y 275, 275-76. Packard notes that, in 2002, an estimated 2.2 million college students will take distance education courses and $85 \%$ of four-year colleges will offer distance education courses. Id.

${ }_{123}$ See Gregory Kent Laughlin, Who Owns the Copyright to Faculty-Created Web Sites?: The Work-forHire Doctrine's Applicability to Intermet Resources Created for Distance Leaming and Traditional Classroom Courses, 41 B.C. L. REV. 549, 556 (2000); Packard, supra note 122, at 276.

${ }^{124} \mathrm{Jed}$ Scully, The Virtual Professorship: Intellectual Property Ownership of Academic Work in a Digital Era, 35 MCGEORGE L. REV. 227 (2004); Weinstein v. Univ. of Ill., 811 F.2d 1091, 1093-94 (7th Cir. 1987) ("The copyright law gives an employer the full rights in an employee's 'work for hire,' ... unless a contract provides otherwise. The statute is general enough to make every academic article a 'work for hire' and therefore vest exclusive control in universities rather than scholars.'). See also Holmes \& Levin, supra note 16, at 165. See also Hays v. Sony Corp. of Am., 847 F.2d 412, 416 (7th Cir. 1988) (noting that "it is widely believed that the 1976 Act abolished the teacher exception," even if it was probably inadvertent).

i25 Hays, 847 F.2d at 416. 
doctrine and the conditions of academic production, and the absence of any indication that Congress meant to abolish the teacher exception" and stated that "if forced to decide the issue" the court might conclude that the exception had survived the 1976 Act. ${ }^{126}$ Yet, the Seventh Circuit ultimately decided that it was not so forced: "We need not try to decide the issue in the present case, for even if the statute abolished the teacher exception this would not necessarily spell victory for Sony." 127 Posner's acknowledgment and discussion of the existence of both a need for a teacher exception as well as a lack of statutory support for such an exception is yet another example of the judicial quandary created by the work for hire doctrine.

The independence of academics would be severely impacted if the scholarship or course materials that they produced are deemed to be work for hire. Professors, a particularly itinerant group, would be restricted from using any of their lecture notes or course materials when they moved from one institution to another. In the well-known case Williams $v$. Weisser, ${ }^{128}$ a UCLA professor brought a copyright infringement action against the publisher of "class notes." The California Court of Appeals, in holding that the professor retained the copyright to his lectures, stated:

Professors are a peripatetic lot, moving from campus to campus. The courses they teach begin to take shape at one institution and are developed and embellished at another. ... Plaintiff testified that the notes on which his lectures were based were derived from a similar course which he had given at another university. If defendant is correct, there must be some rights of that school which were infringed at UCLA. Further, should plaintiff leave UCLA and give a substantially similar course at his next post, UCLA would be able to enjoin him from using the material which, according to defendant, it owns. ${ }^{129}$

Academics tend to develop a body of scholarship that builds upon and borrows from earlier thoughts, writing, and lectures. Given the way that academic work is developed, ownership of such work by universities would raise difficult pragmatic issues with respect to how to define such ownership and how to determine any infringement. ${ }^{130}$

${ }^{126} \mathrm{Id}$.

${ }^{127}$ Id. at 417.

12878 Cal. Rptr. 542 (Cal. Ct. App. 1969).

${ }^{129}$ Id. at 546.

130 As Jed Scully asks: 
In the absence of a teacher exception to the work for hire doctrine, the institution-employer might be deemed to own the rights to any scholarly works written during employment hours. For an academic, the hours of employment are typically ill-defined and unlikely to be interpreted as solely between nine o'clock in the morning and five o'clock in the evening. Thus, an institutionemployer would have the right to modify any materials, including works of scholarship, produced by its faculty even if such modifications are contrary to the beliefs or views held by the writer.

As sound as the teacher exception may be, the nature of academic writings, the express language of 17 U.S.C. $\$ 101$ and the Supreme Court's holding in Reid might result in a finding that academic writings are works for hire. First, using common law principles of agency as required by Reid, professors would almost certainly be considered employees of their university. ${ }^{131}$ While university employers rarely have control over scholarly output, they do provide faculty with benefits, facilities and tools, and an ongoing relationship. ${ }^{132}$ Furthermore, while universities do not "assign" scholarship topics, they are in the business of producing academic research. ${ }^{133}$ Thus, if the writings are prepared by the professor within the scope of the employment, then they will be considered for hire. ${ }^{134}$ A determination of whether a work is prepared within the scope of employment requires consideration of factors such as the type of work the professor was hired to perform, whether the writing was prepared during working hours and at the employer's office, and whether the preparation of the work was subject to the employer's control or motivated by an effort to please the employer. ${ }^{135}$ A strong argument could be made that academic writings meet these

[1] $\mathrm{f}$ we assume that universities generally own or at least can control the copyright output of their academic employees, how is that control to be profitably and practically exercised. Using the Williams $v$. Weisser example, Professor Williams, when hired to teach anthropology at UCLA, brought with him a body of personalized theory, notes, and other material on which he based his teaching. Did UCLA own this preexisting material by virtue of his employment? Hardly. His academic and scholarly output began elsewhere, was refined at UCLA when he was employed there, and was influenced by the input of his students, UCLA peers, and those of his colleagues at other institutions around the country. This itinerant and fugitive nature of academic scholarship is a type of intellectual ferae naturae.

Scully, supra note 124, at 263.

${ }^{131}$ Laughlin, supra note 123, at 572-73.

132 Id.

${ }^{133}$ Id.

134 See Holmes \& Levin, supra note 16, at 187.

135 See Robert A. Kreiss, Scope of Employment and Being an Employee Under the Work-Made-for-Hire Provision of the Copyright Law: Applying the Common-Lan Agengy Tests, 40 U. KAN. L. REV. 119, 126-27 (1991). Kreiss argues that these factors should be replaced by the common law agency test for 
requirements and those created by a professor are within the scope of employment. ${ }^{136}$ Rochelle Cooper Dreyfuss writes:

[The changes in the Copyright Act of 1976] could significantly affect the legal status of faculty work product. Scholars have indeed concluded that the 1976 Act abolishes the teacher exception to the work for hire doctrine. They reason that since the 1976 Act suggests that courts should limit their inquiry to the existence of an employment relationship, employees under long-term contracts-such as academics-may no longer argue that the factors surrounding their employment rebut the presumption of employer ownership. Accordingly, the circumstances under which the work was created and the expectations of the parties have now become largely irrelevant. The dispositive issue is whether production of scholarly material is 'within the scope of employment,' that is, a part of the job. Since scholarship clearly is a factor in decisions regarding tenure, promotion, salary increases, sabbatical leaves, and reduced teaching loads, scholarly works should now belong to universities rather than to faculty members. ${ }^{137}$

Furthermore, while a teacher exception may be warranted to enable professors to reuse or further develop scholarship and lectures created at former places of employment, it is unclear why academics should be able to receive subsequent compensation for work created in the scope of employment whereas other employees cannot. In other words, why should Arthur Miller be able to get paid by Concord University for the same lecture he prepared for Harvard while he is still an employee of Harvard? This is not a situation where Miller left Harvard and went to another institution, bringing with him the materials he prepared while employed at Harvard. In such a case, the teacher exception is justified because of the peculiarities of the academic profession. But why should Miller be allowed to profit twice from the same work when an engineer, for example, would not be able to create a software program for one company and then create that same program for another company? The teacher exception was intended to embody the norms of academia and protect the expectations of academics and their

analyzing scope of employment.

${ }^{136}$ See generally Dreyfuss, supra note 17, at 590 . See also Laughlin, supra note 123, at 576 (" $[\mathrm{I}] \mathrm{t}$ is hard to imagine that a court would find that faculty created scholarly articles, books and teaching materials are not prepared within the scope of employment.").

${ }^{137}$ Dreyfuss, supra note 17 , at 598-99. 
institutions. It should not be used to privilege professors where the benefit is not unique to academia.

On the other hand, it seems reasonable that should Miller leave Harvard, he should be able to take his writings, including his lectures, with him to his new institution. It is generally understood, however, that an engineer leaving an employer would not be able to take work product to a subsequent employer. The work for hire doctrine reflects the expectations of the engineer and employer, but it does not reflect the expectations of professors and academic institutions. While the teacher exception attempts to reflect the norms of academia, it privileges professors even in situations where the subsequent use of the work is for pecuniary purposes only-in other words, in situations where professors are no different, and should therefore be treated no differently, from other employees. It does not protect nonacademic employees who may have a reasonable belief that they can modify or reuse a work they created, and who may have been misled by an employer in this regard. Furthermore, as noted earlier, there is strong support that the 1976 Copyright Act abolished the teacher exception. ${ }^{138}$ Part III proposes amendments to the work for hire doctrine that would address the issues raised by both the creative genius and academic employee situations.

\section{Proposals to Change the "All or Nothing” ApProach of the WORK FOR HIRE DOCTRINE}

The statute defining work for hire requires the judiciary to restrict its analysis to: (1) characterizing the relationship between the hiring party and the creator; and (2) categorizing the work being created. The statute as currently drafted does not permit the court to delve into the intent or the expectations of the parties nor does it provide for the option of shared ownership or a license grant from one party to the other. Thus, if a work is deemed to be a work made for hire, the employer is the author of such work and the copyright vests in the employer, ${ }^{139}$ regardless of the intent of the parties or the custom or practice in a particular industry. In other words, even if the parties had agreed that the employee would

138 See Hays v. Sony Corp. of Am., 847 F.2d 412, 413 (7th Cir. 1988) (noting that it was "widely believed" that the 1976 Copyright Act abolished the teacher exception but that since there was no mention in the legislative history of an intent to abolish the exception, it was probably done inadvertently).

139 See 17 U.S.C. $\$ 201$ (a) (2005) ("Copyright in a work protected under this title vests initially in the author or authors of the work."). Under 17 U.S.C. $\$ 201$ (b):

[i] $n$ the case of a work made for hire, the employer or other person for whom the work was prepared is considered the author for purposes of this title, and, unless the parties have expressly agreed otherwise in a written instrument signed by them, owns all of the rights comprised in the copyright. 
own the copyright and the employer would have an exclusive license to use the work product, if the work is in fact a work for hire under the Copyright Act, such an agreement would be effective only if subsequently transferred in writing ${ }^{140}$ by the author regardless of any understanding of the parties to the contrary. ${ }^{141}$ The all or nothing nature of the work for hire doctrine results in decisions that leave a clear winner and a clear loser, even if such a result defeats the reasonable expectations of the parties. ${ }^{142}$

The impact of this default in favor of the employer is aggravated by the employer's superior bargaining power and access to information. In many cases, the employer is aware of the work for hire doctrine and its implications. A typical employee, however, is often unaware that such a doctrine exists. ${ }^{143}$ Nevertheless, the existing statutory default in favor of the employer reflects the reasonable expectations of the parties if it conforms to industry practice.

For example, a software engineer probably realizes that when she leaves her employer to work for a competitor, she will not be permitted to share code that she has previously developed. While she may be unaware of the existence of the doctrine of work for hire, she is well aware of the norms in her industry which prohibit this type of sharing.

The work for hire doctrine is a default provision which applies in those situations where the parties have failed to expressly address the issue of intellectual property ownership in a written agreement. ${ }^{144}$ This Section proposes amendments to two provisions of the Copyright Act which minimize the

14017 U.S.C. $\$ 201$ (d)(1) provides that "ownership of a copyright may be transferred in whole or in part by any means of conveyance or by operation of law ...." Under 17 U.S.C. $\$ 204(a)$, a "transfer of copyright ownership, other than by operation of law, is not valid unless an instrument of conveyance, or a note or memorandum of the transfer, is in writing and signed by the owner of the rights conveyed or such owner's duly authorized agent."

${ }^{141}$ As Scott Bumham notes, however, a nonexclusive license does not require a written agreement. See Scott J. Burnham, The Interstices of Copyright Law and Contract Law: Finding the Terms of an Implied Nonexclusive License in a Failed Work for Hire Agreement, 46 J. COPYRIGHT SOC'Y U.S.A. $333,351-52$ (1999).

${ }^{142}$ Some courts have, however, examined whether an implied, nonexclusive license exists in the context of a failed work for hire agreement. See, e.g., Lulirama Ltd. v. Axcess Broad. Servs., Inc., 128 F.3d 872 (5th Cir. 1997); Jacob Maxwell, Inc. v. Veeck, 110 F.3d 749 (11th Cir. 1997). For a thorough analysis of these cases, see Burhnam, supra note 141, at 352-57.

143 Elsewhere, I have written about the need for interpretation rules that take into account situations where one party understands the legal significance of a word or phrase such as work for hire and the other party does not. Nancy S. Kim, Evolving Business and Social Norms and Interpretation Rules: The Need for a Dynamic Approach to Contract Disputes, 84 NEB. L. REV. 506 (2005).

144 The author contends that the parties should always be permitted to expressly agree to terms which avoid the effect of the work for hire doctrine. The enforceability of such an agreement would continue to be subject to the standard contract defenses, such as fraud. 
likelihood of unfair surprise and reflect the expectations of the parties in the absence of an express written agreement.

\section{A. THE PROPOSED AMENDMENTS}

1. Amendment to 17 U.S.C. $\int 101$ - Reversing the Statutory Default. The following proposed amendment to 17 U.S.C. $\$ 101$ reverses the default rule that favors the employer in the absence of a written agreement to the contrary.

A 'work made for hire' is ---

(1) a work prepared by an employee within the scope of his or her employment ONLY IF THE PARTIES EXPRESSLY AGREE IN A WRITTEN INSTRUMENT SIGNED BY THEM THAT THE WORK SHALL BE CONSIDERED A WORK MADE FOR HIRE .... (additions are in caps)

The amendment requires a written agreement in order to establish that a work, or specified works, by an employee are works for hire. In the event that there is no written agreement between the employer and the employee, the work would not be considered work for hire and the employee would be the author. This reversal actually reflects the basic precept under Section 201(a) of the Copyright Act that the copyright initially vests in the creator of the work ${ }^{145}$ and diminishes the difference in treatment of work created by employees and independent contractors. ${ }^{146}$ There would remain an important distinction, however, between independent contractors and employees. While only certain statutorily-defined types of work may be considered for hire where the creator is an independent contractor, any work created by an employee would be considered work for hire, provided that there is a written agreement. ${ }^{147}$

As discussed in Part II, the factual circumstances of the parties' relationship currently govern the categorization of work, not the understanding of the parties.

145 See also Sandler, supra note 117, at 247 (stating that the work for hire doctrine is an exception to the basic philosophy of the copyright law).

14617 U.S.C. $\$ 101$ (2000).

147 Only the following types of work may be considered work for hire where the creator is an independent contractor:

work specially ordered or commissioned for use as a contribution to a collective work, as a part of a motion picture or other audiovisual work, as a translation, as a supplementary work, as a compilation, as an instructional text, as a test, as answer material for a test, or as an atlas, if the parties expressly agree in a written instrument signed by them that the work shall be considered a work made for hire. 
Thus, even if the parties expressly agree that a particular work is not a work for hire, if the creating party is an employee and the work is created within the scope of the employment, then the employer is the author notwithstanding any agreement of the parties to the contrary. In the absence of a written agreement between the parties, the employer, which typically has greater knowledge of the law governing work for hire, can potentially take unfair advantage of the existing statutory default.

For example, assume that Sally is a copywriter for an advertising agency. She is also a poet. In an effort to elicit from Sally her "best work," her employer tells her that she is free to submit any copy that she writes for the agency to literary magazines. As a result, Sally pours her heart and soul into the copy that she writes for the agency. Notwithstanding the understanding between Sally and her employer, Sally does not have the right to submit any poems to literary magazines because she is not the ouner of the copyright to those poems. ${ }^{148}$ If her employer subsequently refused to transfer in writing the copyright to Sally, she would be in an unenviable position with respect to her ability to enforce her employer's promise.

Reversal of the statutory default would address the knowledge imbalance typical in individual employment negotiations but would still allow an employer to be the author of the work provided that there is an express written agreement to that effect. The impact on business would be minimal considering that most businesses that hire "creative" employees already have them sign employment agreements containing work for hire provisions. ${ }^{149}$ The software engineer, for example, mentioned in the preceding Section is likely bound by an employment agreement containing both a nondisclosure as well as a work for hire provision to safeguard against a later finding by the judiciary that she was not, in fact, an employee as the parties might have believed. Given the court's focus on the existence of an employment relationship, it is simply wise business policy to require written agreements with all individuals working for the company. Thus, even if someone that an employer considered to be an "employee" is found by a court to be an independent consultant, work created by that individual may still be considered "for hire" if there is a written agreement to that effect. Furthermore, because creations are often patentable, many employers already

148 Most publishers require that contributors be the lawful copyright owners of work that they submit. Therefore, in order for Sally to be able to submit the poems, her employer would need to transfer ownership to her pursuant to a written agreement. See 17 U.S.C. $\$ \$ 201,204$ (governing ownership and transfer of copyright).

${ }^{149}$ This is particularly true after the U.S. Supreme Court's decision in New York Times $v$. Tasini, 533 U.S. 483 (2001). As a result of Tasini, many publishers include a work for hire clause in their employee and freelancer agreements as a matter of course. Maureen A. O'Rourke, Bargaining in the Shadow of Copyright Law After Tasini, 53 CASE W. RES. L. REV. 605 (2003). 
include provisions assigning intellectual property rights in their employment agreements. ${ }^{150}$

Requiring a written agreement to evidence that a work is for hire would likely not result in a sea change of creative works owned by employees. It may only result in more agreements. Yet, a contractual provision making express the ownership by the employer of any employee created work product would bring to the employee's attention the rights of authorship that are being abdicated and perhaps increase the employee's bargaining power with respect to other benefits. In any event, it would provide information that enhances the decision-making abilities of both parties. The current work for hire doctrine is fair only if the employee is aware of it. In reality, however, most employees have never heard of the doctrine, and many of those who have misunderstand what it means. Requiring a written contract that expressly states that the employee's works shall be work for hire corrects, at least to some extent, the bargaining imbalance inherent in potential employment situations.

2. Amendment to 17 U.S.C. $\int 201-E n f o r c i n g$ the Reasonable Expectations of the Parties. Although requiring a written agreement to establish work for hire is a step in the right direction, alone it is insufficient to fulfill the reasonable expectations of the parties. In many situations, the parties anticipate some sort of shared use of the work product which is defeated by the all or nothing nature of 17 U.S.C. $\int 101$. For example, in the case of Martha Graham, it seems unlikely that either Graham or the Center expected that she would be terminated or that she would voluntarily resign as an employee of the Center. The primary purpose of the Center was to facilitate her creative endeavors, and evidence demonstrates that the Center recognized that objective and made every effort to accommodate her wishes. Yet, the parties probably also intended for the Center to be able to have performed the dances that Graham created while an employee of the Center. A court decision in favor of the plaintiff Protas would likely have defeated the expectations of both Graham and the Center in that the Center would not have been able to have Graham's dances performed without receiving Protas's permission. This requirement would have limited the Center's ability to modify and develop her dances without the consent of Protas.

Similarly, while academics may justifiably use previously developed lecture materials and scholarship, there may be instances where a university may reasonably wish to use or develop materials created by former employees. A professor may work with other members of the faculty to create materials for courses that would continue to be offered after the professor's employment

${ }^{150}$ This is especially true where the employee is a scientist or engineer. See ROGER E. SCHECHTER \& JOHN R. THOMAS, INTELIECTUAL PROPERTY: THE LAW OF COPYRIGHTS, PATENTS AND TRADEMARKS 503 (2003). 
terminates or the university might wish to reuse certain exams, lecture notes, or conference materials. It seems contrary to trade norms and to the intent of the parties to make a former university employer liable for infringement claims for continuing to use such materials. Thus, while the parties would not expect the university to distort any materials created by a former professor-employee, it may not be surprising for a university to continue to use materials that were the result of collaborative efforts with other faculty members, or that may have continuing relevance for the university (such as sample exam answers for an existing course) even after the professor's departure from that university.

Both the creative genius and the wandering academic situations illustrate the pitfalls inherent in an all-or-nothing approach to ownership of created works. Although shifting the default rule in favor of the employee may correct initial bargaining inequities, it may still fail to reflect the reasonable expectations of the parties in the absence of an express agreement.

The objective of judicial inquiry in these types of cases should be to determine the reasonable expectations of the parties. In the absence of a written agreement, the court should refer to principles of contract interpretation to determine what the parties intended. The intent of the parties should be the single most important factor to consider in determining ownership. This Article proposes that in addition to reversing the statutory default, the court should consider whether the employer has an implied nonexclusive license ${ }^{151}$ to the work and, if so, the scope of that license. ${ }^{152}$ Because one party has ownership rights to the

151 Although transfers of copyright ownership must be in writing, a "nonexclusive license" is not deemed to be a "transfer of copyright ownership." See 17 U.S.C. $\$ 101$ (2000). See also Burnham, supra note 141, at 351-52.

152 This Article is not the first to advocate finding an "implied license" in certain situations raising work for hire issues. Scott Burnham has written an interesting article discussing situations in which a court might imply a nonexclusive license in the context of a "failed" work for hire agreement. See Burnham, supra note 141. While Burnham's article focuses on the hiring party in a nonemployment context, both his approach and mine advocate first determining the existence of an implied license for the hiring party, and then determining the scope of that implied license. We also both look to contract law to determine the existence of an implied agreement. Our proposed solutions, however, differ. Because Burnham's proposal deals specifically with nonemployment, "failed" work for hire situations, it is not appropriate to determine the rights that an employer might have to a created work. Burnham proposes a "use test" to determine whether an implied nonexclusive license has been granted: "The use test is satisfied if 1) the hiring party has commissioned a work for his use, 2) the hiring party has given value for the work, and 3) the hired party has granted the hiring party no exclusive copyright interest." If these facts are found, then there is an inference that the hiring party has some right to use the work. Id. at 362 . Burnham then proposes using contract principles to determine the scope of the license. By contrast, I propose using contract principles to determine the existence of an implied license, and guidelines (set forth in Part III.A.2.b) to determine the scope of the license. These guidelines take into account both the public and the employer's interest in the work and focus on the nature of the creation. Bumham, on the other hand, considers the nature of 
work by statutory default should not mean that the other party has no rights to it. In fact, the parties might have assumed that both parties would have ownership rights, or that one party might have rights to use the work that is owned by the other party. Thus, where an employee creates a work within the scope of employment and there is no written agreement specifying ownership, the courts should determine (1) whether the employer has any rights to the work and if so, (2) the nature and scope of such rights.

a. Does the Employer Have an Implied License to the Work? First, the courts should determine whether the employer has any rights to the work. For the reasons stated in Part III.A.1, the employer should have the burden of having the employee sign an assignment or work for hire agreement, prior to hiring the employee. Where the parties have failed to execute such an agreement, the employee owns the work, yet the parties may have expected the employer to have some rights to the work. ${ }^{153}$

i. Purpose of the Employment. In order to determine intent, courts should first examine the purpose of the employment. ${ }^{154}$ Why did the parties enter into the employment relationship? Why did the employer hire the employee? Some types of employment are generally expected to result in creation of a work that the employer intends to use.

In the Grabam case, the purpose of hiring Martha Graham was to promote the art of dance and to facilitate Graham's creative efforts. In fact, the corporation's very existence was to facilitate Graham's endeavors.

Similarly, in Miller's case, the court would first examine why Harvard hired Miller. Generally, academics are hired to educate students and to establish or enhance the university's reputation through scholarship. That objective is not diminished by permitting the employee to retain ownership of scholarship. In fact, one could argue that ownership by the university as opposed to the professor might reduce the credibility, and thus the value, of the work product since scholarship is expected to be developed free from institutional influence. Similarly, the school's purpose in hiring Miller is not lessened by enabling him to reuse his course materials at a subsequent place of employment; however, this purpose is negatively affected by his efforts to use those same course materials for the benefit of another institution while employed at Harvard. Thus while Miller should be permitted to retain ownership of the course materials, his ability to use

the work in determining whether a license exists at all.

153 Permitting the employer to have an implied license to a copyrighted work is akin to the "shop right" for employers under the common law governing patents. See SCHECHTER \& THOMAS, supra note 150 , at 503 .

${ }^{154}$ See Spaulding v. Morse, 76 N.E.2d 137 (Mass. 1947); Haines v. New York, 364 N.E.2d 820 (N.Y. 1977). 
them while an employee of Harvard may be restricted by Harvard's interest in the work (depending on the outcome of the analysis in the remainder of Part III.A.2).

ii. Industry Norms. Courts should also consider trade usage and industry norms in determining whether the work is of the type that the employer should reasonably be permitted to use. ${ }^{155}$ Contract law has long recognized the relevance of trade usage in resolving ambiguities in language. ${ }^{156}$ Modern courts, as well as the Restatement and the UCC, supplement contract terms with trade usage, unless the parties have specifically stated otherwise. ${ }^{157}$ In most situations, the parties are aware of the industry norms and trade usage and thus referring to such to supplement their agreement furthers their contractual intent and protects their reasonable expectations. ${ }^{158}$ For example, in academia it is typical for professors to retain rights to scholarly works.

The difficulties arise where industry norms have not yet been established, either because the situations are unique (as in Grabam where the employer existed primarily to facilitate the creative efforts of the employee) or because technological advancements have changed the industry in some fundamental way (such as in the case with Miller and Harvard Law School, where distance learning created the possibility of substantial income from previously low-revenue generating works). In these "first impression" cases, the court should examine not just the circumstances at the time of contract formation, but the circumstances leading up to and existing at the time of the dispute. This Article advocates a "dynamic" approach to the analysis of work product ownership which considers not just the circumstances at the time the contract was formed, but subsequent events which affect the expectations of the parties. ${ }^{159}$ The purpose of the inquiry is not, however, to determine what a reasonable person would have agreed to under the circumstances but what these parties would have agreed to if

155 Kreiss, supra note 32, at 124-25.

156 See Berwick \& Smith Co. v. Salem Press, Inc., 117 N.E.2d 825 (Mass. 1954); Hurst v. W.J. Lake \& Co., 16 P.2d 627 (Or. 1932).

157 See RESTATEMENT SECOND OF CONTRACTS (1981), $\$$ 220-222; U.C.C. $\$ \$ 1-201(3), 1-303$ (1977).

${ }^{158}$ A party may, however, be a newcomer to the industry and unaware of the norms. In such cases, some courts have held that it is not realistic to say that a neophyte "had reason to know" of a particular custom. See Flower City Painting Contractors, Inc. v. Gumina Constr. Co., 591 F.2d 162 (2d Cir. 1979).

159 See Melvin Aton Eisenberg, Symposium on Lav in the Twentieth Century: The Emergence of Dynamic Contract Law, 88 CAL. L. REv. 1743, 1762 (2000) (Dynamic contract law does not depend "solely on what occurred at the moment in time when a contract was formed, but instead turn[s] on the moving stream of events that precedes, follows, or constitutes the formation of a contract"). See also Kim, supra note 143, at 508 ("Dynamic contract law] views the contract not as a written text frozen in time with two purely rational actors as parties, but as an exchange of words and acts between two individuals with varying experiences, against a backdrop of changing circumstances.'). 
they had considered the scenario at hand. To put it another way, it would be too speculative to guess what the parties might have done in a first impression situation; thus, in the absence of evidence to the contrary, the factfinder should assume that the parties would have acted like reasonable people. If, however, there is evidence that the parties would have behaved differently, then the courts should consider such evidence, provided that it is reliable. ${ }^{160}$

b. The Scope of the Implied License. If the court determines that, given the purpose of employment and industry norms, it is reasonable to grant the employer an implied license to the work, it must next determine the scope of that implied license. What should the employer be permitted to do with the work? Keeping in mind the objective of Copyright Law to provide a temporary monopoly in order to benefit the public, ${ }^{161}$ the scope of the license should be determined by first examining whether the employer is in a better position to exploit the work than the employee. In this context, "exploit" means the ability to maximize the utility of the work. This inquiry determines the scope of the employer's right, keeping in mind the public interest. An employer who should reasonably be permitted to use the work and who is in a better position to exploit the work, should also be deemed to have a license to modify or develop that work provided that it acknowledges that the work has been created by the employee and then subsequently modified or developed by the employer. Because copyright law aims to promote and protect the public's interest, enabling an employer to modify and develop a work that it should be reasonably permitted to use increases the likelihood that the work will reach the public.

Finally, the court should determine whether the employer had substantial input or control over the work. In certain situations, the employer's contributions to the creation of the work may be so significant, that the employer may have a license that is so broad and unrestricted that it is in many respects similar to a joint ownership right in the work. ${ }^{162}$

The aforementioned guidelines focus not on the existence of an employment relationship, but on the nature of the work at issue. The determination of ownership will differ depending not on who the parties are, but on what the work is. Under

${ }^{160}$ This emphasis on the subjective intent of the parties reflects the shift of modern contract law away from objective and standardized rules to those that are individualized. See Eisenberg, supra note 159 , at $1754-58$.

i61 See Twentieth Century Music Corp. v. Aiken, 422 U.S. 151, 156 (1975) (stating that the objective of copyright law is to provide an incentive "to stimulate artistic creativity for the general public good').

162 Any such license would be without a right to an accounting of profits, given the administrative difficulties that would ensue in these types of situations. The author also acknowledges that as a practical matter, the success of a particular work product in the marketplace often depends as much, if not more, on marketing execution than on the innovativeness of the product. 
this analysis, a university is more likely to have an interest in course materials than in the scholarship produced by a professor-even though both types of work may have been created while the professor was employed by the university, using university facilities, and during "working" hours. ${ }^{163}$

In the case of Professor Miller, the law school had never previously laid claim to his course materials, yet the prospect of revenue from online courses had altered the traditional landscape of academia. Each party could credibly claim that if the possibility of selling course materials online had been considered, the party would have claimed an ownership interest from the beginning. Notwithstanding ownership by Miller (which would be mandated by adoption of the default proposed in Part III.A.1 absent a written agreement to the contrary), does Harvard also have some type of interest in Miller's work? Does it have a reasonable claim to Miller's course materials? In certain situations it might. If, for example, Miller had created a tutorial that he then placed on his website, it might be reasonable to allow the law school to continue to use that tutorial even after Miller's departure. This would wrest exclusive rights away from Miller but would not impair or hinder his subsequent use of the same material-it would only enable the law school to continue to use it without his permission.

The second question the court should ask is whether Harvard is in a better position to exploit the course materials than Miller. Harvard has substantially more assets as well as access to thousands of students. Yet, despite its superior resources, Harvard is not in a better position to exploit Arthur Miller's work than Miller himself. Miller is in the best position to further develop the course materials, to modify them, and to defend and clarify their meaning. Thus, while Harvard may be permitted to use the materials as is, it should not be able to further develop them.

Furthermore, since Harvard did not provide any input or assert any control over Miller's course materials, it should not get a share of the revenues or be able to prevent Miller from subsequent use of the materials. ${ }^{164}$ In other words, Harvard should not have a broad, unrestricted license to use Miller's course materials but only a limited license to use the materials as is.

This "nature of the work" analysis would differ for Martha Graham. Under the proposed default in favor of the employee, Graham would retain ownership

${ }^{163}$ Because a university may have "some" interest in the course materials, does not mean it owns the copyright. See infra Part II.

164 Harvard may be able to prevent Miller from working with Concord under his employment agreement's "conflict of interest" provision. The issue, however, in this section is whether Harvard would be able to prevent Miller from providing the materials to Concord because Harvard has some interest in the materials. 
of her dances unless the parties had agreed otherwise in writing. Yet, does (or should) the Center also have an interest in Graham's dances?

First, it seems reasonable to permit the Center to stage productions of Graham's dances without her permission. While the Center may have been created to facilitate Graham's endeavors, its purpose-as stated in its certificate of incorporation-was to "teach the science and art of the dance" and to "compose, perform and demonstrate, and to commission the composition, performance and demonstration of dances, ballets, dramas and music." 165 As a dance teacher and choreographer of the Center herself, Graham was fully aware of the purpose of the Center. Furthermore, she had sold her own dance school (that she had been operating as a sole proprietorship) to the Center. ${ }^{166}$

Second, the Center may be in a better position to exploit Graham's work. It has greater resources to publicize and produce her work than she may have as an individual. In contrast to the Miller case where the work product was law school course materials, the nature of creative dances would seem more susceptible to modification or further development by an individual different from the creator (provided, of course, that there was no misrepresentation or misattribution of the subsequent modifications or developments). Dances are especially vulnerable as an art form and rely more upon subsequent dancers and performances than the original choreographer for their continued existence. ${ }^{167}$ Senta Driver, a choreographer and former Paul Taylor dancer, observed, "A dance legacy is sustained by someone else, and dancers need to face that fact. It's the nature of the art of dance." 168 There is an even stronger argument in the Grabam case regarding the Center's ability to exploit the work in the actual case. While the Center may only be marginally better suited to exploit Graham's work than Martha Graham herself, it is clearly in a better position than her beneficiary, Protas, who has no professional dance experience and few friends in the world of dance production. ${ }^{169}$ Because the Center is in a much better position to exploit the work than is Protas, in order to increase the public's access to the works, the

165 Grabam I, 224 F. Supp. 2d 567, 572 (2d Cir. 2004).

166 Id.

${ }^{167}$ As one writer has commented,

Repertory dance companies are museums, but living museums, subject more than most artistic institutions to the frailties, choices and whims of human beings. Most dances are lost; those that survive exist in altered form. Choreographers know this; many are ambivalent about the fate of their work after their death. Inevitably, it's left to others to carry on a dance legacy, even one as vital as Martha Graham's.

Jennifer de Poyen, supra note 108.

${ }^{168}$ Id.

169 See supra discussion Part II. 
Center should be permitted to modify and develop the works (with proper attribution) without seeking his permission as the copyright holder. By the same token, care should be taken to ensure that there is no confusion that the modifications were not made by Graham herself. ${ }^{170}$

Finally, because the Center had no input or control over Graham's creation of her dances, it should not have any ability to control either her (or, in the actual case, Protas's) use of them. Both the Center and Protas should be permitted to stage dance productions of Graham's work without accounting to the other.

c. Text of Proposed Amendment to 17 U.S.C. $₫ 201$.

(f) Implied License. An employer may acquire certain rights to a work that is not a work for hire under Section 101 if the work is prepared by an employee within the scope of employment and the work is of the type that the employer should reasonably be permitted to use given the purpose of employment and industry norms and customs. The scope of the implied license shall be determined by the employer's ability to exploit the work and the employer's input and control over the creation of the work. Notwithstanding the foregoing, unless otherwise agreed to by the parties in a written agreement, any modification of the work by the employer shall expressly identify the employee as the author of the work, and the employer as the party responsible for the modifications.

\section{CONCLUSION}

The all-or-nothing nature of the work for hire doctrine creates a quandary for the judiciary in situations where the putative employee is a creative genius, such as Martha Graham, or an academic, such as Professor Arthur Miller. The exclusive and absolute concept of ownership under the work for hire doctrine may in those cases undermine the reasonable expectations of the parties. This Article advocates several changes to the 1976 Copyright Act which would better

170 The creator should not be forced to have his or her name associated with modified or derivative works of which he or she disapproves. As Cooper Dreyfuss notes,

Like a good trade name, a good reputation enables others to identify the human and intellectual resources that are most likely to contribute to progress. Thus, the rights to control attribution and to protect the integrity of the work advance the interests of information users, whose search costs are reduced when reputations and output are protected from interference by others.

Dreyfuss, supra note 17 , at 644 . The licensee should take care to ensure that any attribution does not mislead or confuse the public. 
effectuate the intent of the parties in an employment relationship. First, a written agreement should be required to establish that a work is "for hire," for both employees and independent contractors. This reversal of the current statutory default seeks to prevent unfair surprise and address the knowledge inequity that often exists where one party is a potential employee and the other an employer. The second proposed change focuses on the scope of employment in situations where a written work for hire agreement has not been executed by the parties. The objective of the scope of employment analysis is to determine whether the employer has any rights to the work notwithstanding ownership by the employee. After establishing that the work was created by an employee within the scope of employment, the court should determine the nature and scope of the license that should be granted to the employer by taking into account industry norms, the employer's ability to exploit the work, and the significance of any contributions made by the employer to the work.

Like other contracting parties, an employee and an employer make certain assumptions about their relationship which shape their expectations. The current work for hire doctrine disregards their expectations and their intent in entering into the employment relationship. The proposed changes to the work for hire doctrine reflect the way parties actually do business, and undo the judicial bind created by the all or nothing concept of ownership under the existing statute. 